\begin{tabular}{l} 
RECORDS OF PHARMACEUTICAI \\
\hline AND BIOMIEDICAI SCIENCES
\end{tabular}

\title{
Synthesis and characterization of a new spirooxindole grafted pyrrolidino/piperidine moiety
}

\author{
Yasmine M. Abdel Azizia, ${ }^{a}$, Gehad Lotfy ${ }^{a}$, Mohamed M. Said ${ }^{a}$, El Sayed H. El Ashryb, El Sayed \\ H. El Tamanyc, Saied M. Soliman ${ }^{\mathrm{b}}$, Matti Haukka ${ }^{\mathrm{d}}$, Assem Barakate, \\ ${ }^{a}$ Pharmaceutical Organic Chemistry Department, Faculty of Pharmacy, Suez Canal University, Ismailia \\ 41522, Egypt. \\ ${ }^{b}$ Department of Chemistry, Faculty of Science, Alexandria University, Alexandria 21321, Egypt. \\ ${ }^{c}$ Department of Chemistry, Faculty of Science, Suez Canal University, Ismailia, Egypt. \\ ${ }^{d}$ Department of Chemistry, University of Jyväskylä, FI-40014 Jyväskylä, Finland \\ ${ }^{e}$ Department of Chemistry, College of Science, King Saud University, Riyadh 11451, Saudi Arabia.
}

Received on: 05.12.2020

Revised on: 25.12.2020

Accepted on: 27.12.2020

Correspondence Author:

E-mail address:

yassmin_morsy@pharm.suez.edu.eg

ambarakat@ksu.edu.sa

\begin{abstract}
In this text, we synthesized and characterized a new spirooxindole grafted pyrrolidino/piperidine moieties. The new hit obtained via one-pot reaction of the chalcone based cyclohexanone with the isatin and (R)-piperidine-2-carboxylic acid in $\mathrm{MeOH}$ under reflux for $48 \mathrm{~h}$. The compound exclusively obtained in regio-selective and diastereo-selective manner. The chemical feature of the target compound is confirmed by ${ }^{1} \mathrm{H}$ NMR and ${ }^{13} \mathrm{C}$ NMR spectroscopy. In addition, we reported for the first time the X-ray single crystal structure of isatin. Its molecular packing depends mainly on strong $\mathrm{O} \ldots \mathrm{H}$ hydrogen bonds and $\pi-\pi$ stacking interactions as well as weak H...H and H...C contacts. Using DFT calculations, isatin is a polar molecule with a net dipole moment of 5.912 Debye. Also, the calculated structure agreed very well with the experimental one. The charge distribution at the different atomic sites is calculated using NBO calculations.
\end{abstract}

Keywords: Spirooxindole, pyrrolidino/piperidine DFT, Hirshfeld analysis.

\section{Introduction}

Drug discovery and modern medicinal chemistry with the tremendous progress by discovering the natural and synthetic products have been gain much attention ( $\mathrm{Li}$ et al., 2018). In the past century, natural products have been achieved enormous success in the drug innovation in the area of oral availability, biological compatibility, but the drug-resistance remain a challenge for the most natural products with potential pharmacological effects. Therefore, pharmacologists and chemists gave a more attention to diverse the functional diversity and structural features of natural products, with an aim to overcome the existing problems. Specifically, 
the alkaloids spirooxindole scaffold, as a class member of the oxindole environmentally natural products (Kaur et al., 2016), (Tantawy et al., 2017), (Newman et al., 2016). The first example was first isolated from Apocynaceae and Rubiaceae plants. The spirooxindole scaffold is a privileged structure consisting of two basic substructure units: the first unit is oxindole with multiple functionality, which can acts as acceptors or donors with the biological targets via hydrogen bonding interaction. The second unit is a carbocyclic or heterocyclic moiety fused with oxindole ring at the $\mathrm{C}-3$ position. It provides an opportunity to regulate many physicochemical properties and the liposolubility of spirooxindole (e.g: anti-inflammatory, anticancer, analgesic, antimicrobial, antimalarial, antioxidant, antiviral, antidiabetic, antiatherosclerotic, and insecticidal activities) and unique spatial architecture of spirooxindole have got a remarkable attention of many pharmacologists and chemists (Tantawy et al., 2017). Accordingly, the significant biological activities (Arun et al., 2013), (Lotfy et al. 2017), (maiulo et al., 2018) (Barakat et al., 2018), (Lotfy et al., 2018), (Lotfy et al., 2019), (Barakat et al., 2020).

In this text, we applied the combinatorial approach of the 1,3-dipolar cycloaddition between chalcone based cyclohexanone with isatin and the (R)piperidine-2-carboxylic acid to synthesize a new spirooxindole hit. In addition, for the first the Xray single crystal and the supramolecular structures of isatin are presented. Also, its electronic aspects were analyzed using DFT calculations.

\section{Experimental}

\subsection{General}

The ${ }^{1} \mathrm{H}$ NMR and ${ }^{13} \mathrm{C}$ NMR spectra of a new spirooxindole hit 4 were recorded on a JEOL 400MHz spectrometer (JEOL, Ltd, Tokyo, Japan) at ambient temperature. The solvent used was DMSO- $d_{6}$; the chemical shifts $(\delta)$ were given in ppm. Single crystal X-ray data of isatin 2 were collected on a Rigaku Oxford Diffraction Supernova diffractometer at $120 \mathrm{~K}$.

\section{(3'R)-3-((E)-benzylidene)-2'-phenyl-6',7', $8^{\prime}, 8 a^{\prime}$ - tetrahydro-2'H,5'H-dispiro[cyclohexane-1,1'- indolizine-3',3"-indoline $]-2,2$ '-dione 4}

A mixture of 2,6-di((E)-benzylidene)cyclohexan1-one 1 ( $137 \mathrm{mg}, 0.5 \mathrm{mmol})$, isatin 2 ( $73.5 \mathrm{mg}, 0.5$ $\mathrm{mmol})$ and $(R)$-piperidine-2-carboxylic acid $\mathbf{3}$ (64.5mg, $0.5 \mathrm{mmol})$ in methanol $(10 \mathrm{~mL})$ was refluxed on oil bath for $1 \mathrm{~h}$. After completion of the reaction as evident from TLC, the mixture was kept for slow evaporation. The resulting solid was filtered and recrystallized from ethanol to yield a faint yellow powder (207.5 mg, $0.42 \mathrm{mmol}, 85 \%)$. m.p: $154-155{ }^{\circ} \mathrm{C}$; IR $\left(\mathrm{KBr}, \mathrm{cm}^{-1}\right): 3255,2939$, $1710,1620,1535,1490,1260 ;{ }^{1} \mathrm{H}$ NMR (400 MHz, CHLOROFORM-D) $\delta 8.67(\mathrm{~s}, 1 \mathrm{H}), 7.37(\mathrm{t}$, $J=7.3 \mathrm{~Hz}, 2 \mathrm{H}), 7.33-7.12(\mathrm{~m}, 8 \mathrm{H}), 7.09-6.98$ $(\mathrm{m}, 2 \mathrm{H}), 6.99(\mathrm{~s}, 1 \mathrm{H}), 6.94(\mathrm{~s}, 1 \mathrm{H}), 6.75(\mathrm{~d}, J=7.9$ $\mathrm{Hz}, 1 \mathrm{H}), 4.40(\mathrm{~d}, J=10.3 \mathrm{~Hz}, 1 \mathrm{H}), 3.80(\mathrm{t}, J=$ $10.3 \mathrm{~Hz}, 1 \mathrm{H}), 2.40(\mathrm{dt}, J=15.2,3.9 \mathrm{~Hz}, 2 \mathrm{H}), 2.23$ (s, 2H), 2.19 (d, $J=11.0 \mathrm{~Hz}, 0 \mathrm{H}), 2.11(\mathrm{q}, J=8.5$ $\mathrm{Hz}, 1 \mathrm{H}), 1.72$ (dd, $J=23.4,11.2 \mathrm{~Hz}, 2 \mathrm{H}), 1.44$ (t, $J=7.1 \mathrm{~Hz}, 1 \mathrm{H}), 1.34(\mathrm{dq}, J=8.8,4.3 \mathrm{~Hz}, 3 \mathrm{H})$, $1.34-1.15(\mathrm{~m}, 2 \mathrm{H}), 1.08(\mathrm{dt}, J=15.6,8.0 \mathrm{~Hz}$, $1 \mathrm{H}) ;{ }^{13} \mathrm{C}$ NMR (101 MHz, CHLOROFORM-D) $\delta$ $202.41,178.30,141.53,138.90,138.28,137.93$, $136.03,130.52,129.87,129.77,129.12,128.20$, $126.71,122.79,109.33,63.38,62.10,56.04,45.67$, 31.08, 28.67, 25.72, 23.98, 20.04, 1.13; LC/MS (ESI): $489.25[\mathrm{M}+\mathrm{H}]^{+}$; Anal. for $\mathrm{C}_{33} \mathrm{H}_{32} \mathrm{~N}_{2} \mathrm{O}_{2}$; calcd C, 81.12; H, 6.60; N, 5.73.; Found: C, 81.22; H, 6.63; N, 5.784 .

\subsection{Single-Crystal X-Ray Diffraction Analysis}

$\mathrm{X}$-ray diffraction data of target molecule was collected on Bruker D8 Venture Diffrectometer with the aid of $\mathrm{Cu} K \alpha(\lambda=0.71073 \AA)$ radiation source and CMOS Photon 100 detector 100. Data integration, and reduction were carried out by APEX 3 software package (Rikagu et al., 2018) followed by use of SHELXL programs to solve and refine the final structure (Sheldrick et al., 2015), Table 1. Geometrical calculations and intermolecular interaction studies were performed on PLATON and Mercury 3.10.1, respectively (Sheldrick et al., 2015), (Hubschle et al., 2011). ORTEP diagram, Fig. 1, described the threedimensional representation of title compound.

\subsection{Hirshfeld surface analysis}

The topology analyses were performed using Crystal Explorer 17.5 program (Turner et al., 2017).

\subsection{Computational methods}

All DFT calculations were performed using Gaussian 09 software package (Frisch et al., 2007) utilizing B3LYP/6-31G(d,p) method. Natural charge populations were performed using NBO 3.1 
program as implemented in the Gaussian 09W package (Reed et al., 1988).

\section{Results and Discussion}

\subsection{Chemistry}

The synthesis of the new substituted spirooxindole is outlined in Scheme 1. Multi-component one-pot reaction approach to furnish the requisite compound in a high purity as well as regioselective and diastero-selective fashion was employed. Assignment of the chemical features of the substituted spirooxindole analogue is based on the spectrophotometric techniques. ${ }^{1} \mathrm{H}$ NMR and ${ }^{13} \mathrm{C}$ NMR spectra showed all features of corrected protons and carbon, respectively, Figures 1 and 2.

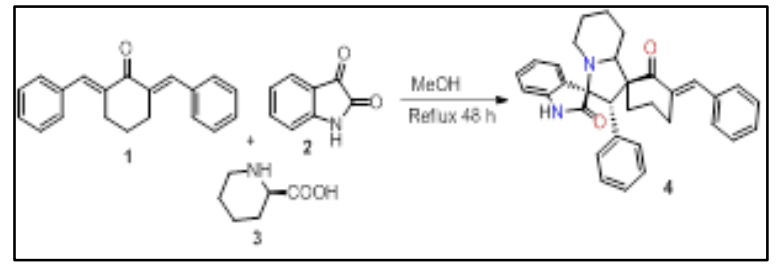

Scheme 1. Synthesis of the spiroxindole derivative 4

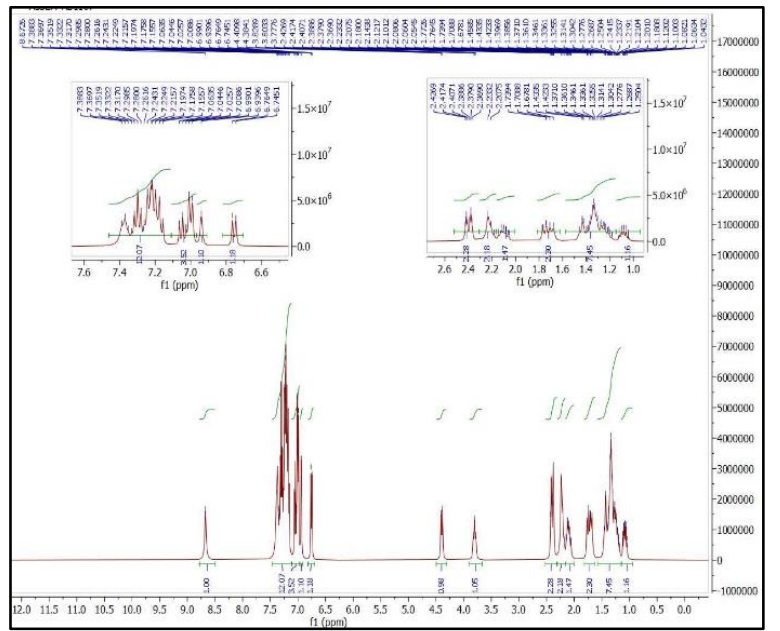

Figure 1. ${ }^{1}$ HNMR of spiroxindole derivative 4

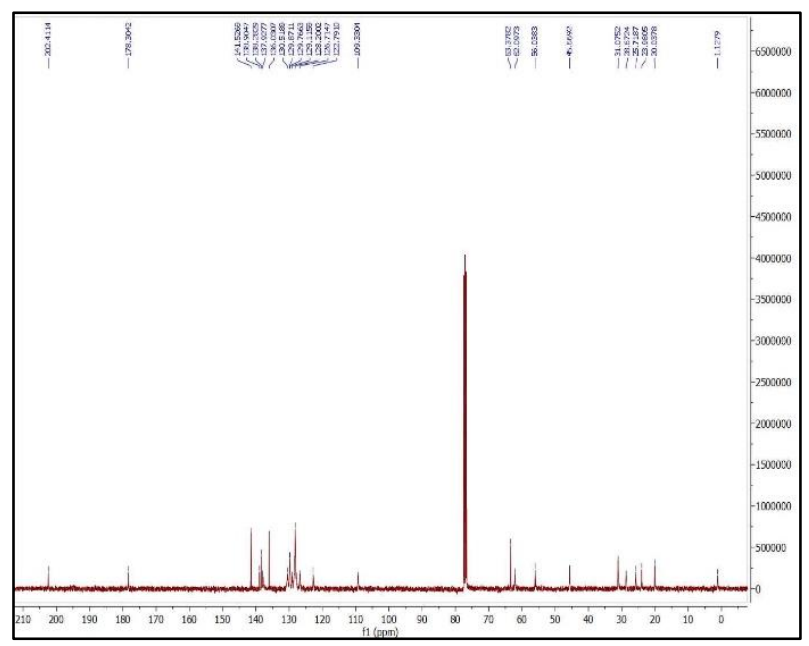

Figure $2 .{ }^{13} \mathrm{CNMR}$ of spiroxindole derivative 4 3.2. Crystal Structures of Compound 2

A suitable single crystal obtained by slow evaporation of the isatin in EtOH. Isatin is crystallized in monoclinic crystal system and space group $\mathrm{P} 2{ }_{1} / \mathrm{c}$ with one molecule per asymmetric unit and $Z=4$. The structure details and refinement parameters are listed in Table 1. The X-ray structure with thermal ellipsoids at $50 \%$ probability level along with atom numbering is given in Figure 3 while the bond distances and angles are listed in Table 2.

Table 1. Crystal and refinements data of isatin 2

\begin{tabular}{|c|c|c|}
\hline CCDC No. & 2034244 & \\
\hline Empirical formula & $\mathrm{C}_{8} \mathrm{H}_{5} \mathrm{NO}_{2}$ & \\
\hline Formula weight & 147.13 & \\
\hline Temperature & $120(2) \mathrm{K}$ & \\
\hline Wavelength & $1.54184 \AA$ & \\
\hline Crystal system & Monoclinic & \\
\hline Space group & $\mathrm{P} 2{ }_{1} / \mathrm{c}$ & \\
\hline \multirow[t]{3}{*}{ Unit cell dimensions } & $a=6.1475(3) \AA$ & $\alpha=90^{\circ}$ \\
\hline & $\mathrm{B}=14.5787(7) \AA$ & \\
\hline & $c=7.0751(4) \AA$ & $\gamma=90^{\circ}$ \\
\hline Volume & $632.73(6) \AA^{3}$ & \\
\hline $\mathrm{Z}$ & 4 & \\
\hline Density (calculated) & $1.545 \mathrm{Mg} / \mathrm{m}^{3}$ & \\
\hline Absorption coefficient & $0.950 \mathrm{~mm}^{-1}$ & \\
\hline $\mathrm{F}(000)$ & 304 & \\
\hline Crystal size & $0.152 \times 0.062 \times$ & \\
\hline & $0.043 \mathrm{~mm}^{3}$ & \\
\hline $\begin{array}{l}\text { Theta range for data } \\
\text { collection }\end{array}$ & 6.071 to $76.544^{\circ}$. & \\
\hline Index ranges & $\begin{array}{l}-7<=\mathrm{h}<=5,- \\
18<=\mathrm{k}<=16,- \\
8<=\mathrm{l}<=7\end{array}$ & \\
\hline Reflections collected & 3820 & \\
\hline $\begin{array}{l}\text { Independent } \\
\text { reflections }\end{array}$ & $\begin{array}{l}1298[R(\text { int })= \\
0.0243]\end{array}$ & \\
\hline $\begin{array}{l}\text { Completeness to theta } \\
=67.684^{\circ}\end{array}$ & $100.0 \%$ & \\
\hline Absorption correction & Gaussian & \\
\hline $\begin{array}{l}\text { Max. and min. } \\
\text { transmission }\end{array}$ & 1.000 and 0.744 & \\
\hline Refinement method & $\begin{array}{l}\text { Full-matrix least- } \\
\text { squares on } \mathrm{F}^{2}\end{array}$ & \\
\hline $\begin{array}{l}\text { Data / restraints / } \\
\text { parameters }\end{array}$ & $1298 / 0$ / 104 & \\
\hline Goodness-of-fit on $\mathrm{F}^{2}$ & 1.047 & \\
\hline $\begin{array}{l}\text { Final } R \text { indices } \\
{[\mathrm{I}>2 \operatorname{sigma}(\mathrm{I})]}\end{array}$ & $\begin{array}{l}\mathrm{R} 1=0.0381 \\
\mathrm{wR} 2=0.0986\end{array}$ & \\
\hline
\end{tabular}




\begin{tabular}{ll}
\hline R indices (all data) & R1 =0.0466, \\
& wR2 $=0.1041$ \\
Extinction coefficient & n/a \\
Largest diff. peak and & 0.327 and -0.200 \\
hole & e. $\AA^{-3}$ \\
\hline
\end{tabular}

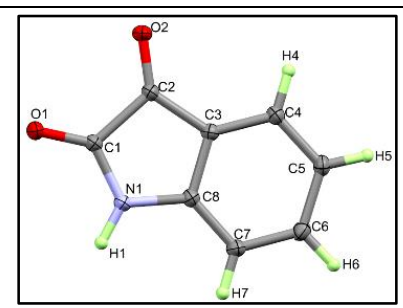

Figure 3. X-Ray structure with atom numbering and thermal ellipsoids at $50 \%$ probability level for isatin

Table 2. Selected bond lengths $[\AA ̊ \mathrm{~A}]$ for isatin

\begin{tabular}{|l|l|l|l|}
\hline Bond & Distance & Bond & Angle \\
\hline $\mathrm{O}(1)-\mathrm{C}(1)$ & $1.2193(18)$ & $\mathrm{C}(1)-\mathrm{N}(1)-\mathrm{C}(8)$ & $111.50(12)$ \\
\hline $\mathrm{O}(2)-\mathrm{C}(2)$ & $1.2092(18)$ & $\mathrm{O}(1)-\mathrm{C}(1)-\mathrm{N}(1)$ & $127.99(13)$ \\
\hline $\mathrm{N}(1)-\mathrm{C}(1)$ & $1.3512(19)$ & $\mathrm{O}(1)-\mathrm{C}(1)-\mathrm{C}(2)$ & $126.18(13)$ \\
\hline $\mathrm{N}(1)-\mathrm{C}(8)$ & $1.4094(18)$ & $\mathrm{N}(1)-\mathrm{C}(1)-\mathrm{C}(2)$ & $105.83(12)$ \\
\hline $\mathrm{C}(1)-\mathrm{C}(2)$ & $1.5662(19)$ & $\mathrm{O}(2)-\mathrm{C}(2)-\mathrm{C}(3)$ & $131.42(13)$ \\
\hline $\mathrm{C}(2)-\mathrm{C}(3)$ & $1.4630(19)$ & $\mathrm{O}(2)-\mathrm{C}(2)-\mathrm{C}(1)$ & $123.76(13)$ \\
\hline $\mathrm{C}(3)-\mathrm{C}(4)$ & $1.388(2)$ & $\mathrm{C}(3)-\mathrm{C}(2)-\mathrm{C}(1)$ & $104.82(11)$ \\
\hline $\mathrm{C}(3)-\mathrm{C}(8)$ & $1.400(2)$ & $\mathrm{C}(4)-\mathrm{C}(3)-\mathrm{C}(8)$ & $120.71(13)$ \\
\hline $\mathrm{C}(4)-\mathrm{C}(5)$ & $1.394(2)$ & $\mathrm{C}(4)-\mathrm{C}(3)-\mathrm{C}(2)$ & $132.19(13)$ \\
\hline $\mathrm{C}(5)-\mathrm{C}(6)$ & $1.395(2)$ & $\mathrm{C}(8)-\mathrm{C}(3)-\mathrm{C}(2)$ & $107.10(12)$ \\
\hline $\mathrm{C}(6)-\mathrm{C}(7)$ & $1.395(2)$ & $\mathrm{C}(3)-\mathrm{C}(4)-\mathrm{C}(5)$ & $118.47(14)$ \\
\hline $\mathrm{C}(7)-\mathrm{C}(8)$ & $1.379(2)$ & $\mathrm{C}(4)-\mathrm{C}(5)-\mathrm{C}(6)$ & $119.86(14)$ \\
\hline & & $\mathrm{C}(7)-\mathrm{C}(6)-\mathrm{C}(5)$ & $122.16(14)$ \\
\hline & & $\mathrm{C}(8)-\mathrm{C}(7)-\mathrm{C}(6)$ & $117.21(14)$ \\
\hline & & $\mathrm{C}(7)-\mathrm{C}(8)-\mathrm{C}(3)$ & $121.59(13)$ \\
\hline & & $\mathrm{C}(7)-\mathrm{C}(8)-\mathrm{N}(1)$ & $127.67(13)$ \\
\hline & & $\mathrm{C}(3)-\mathrm{C}(8)-\mathrm{N}(1)$ & $110.74(12)$ \\
\hline
\end{tabular}

Molecular packing of compound 2 is controlled mainly by strong N1-H1 ...O1 hydrogen bond. The hydrogen bond parameters are given in Table 2 where each two isatin molecules form a hydrogen bonded dimer as shown in Figure 4. Donoracceptor distance for this interaction is 2.902(2) Á.

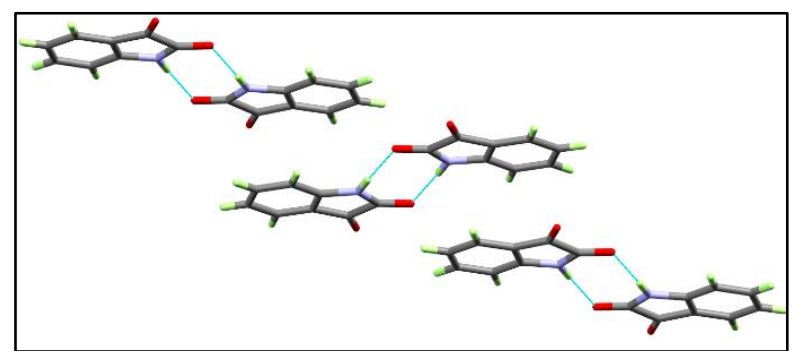

Figure 4. Molecular packing of isatin molecules via N-H...O hydrogen bonds
Table 3. Hydrogen-bond geometry $(\AA)$

\begin{tabular}{|c|c|c|c|c|}
\hline$D-\mathbf{H} \cdots A$ & $D-\mathbf{H}$ & $\mathbf{H} \cdot \cdot \boldsymbol{A}$ & $D \cdot \cdot A$ & $D-\mathbf{H} \cdot \cdot A$ \\
\hline $\begin{array}{l}\mathrm{N}(1)- \\
\mathrm{H}(1) \ldots \mathrm{O}(1) \# 1\end{array}$ & $\begin{array}{l}0.91 \\
(2)\end{array}$ & $\begin{array}{l}2.00 \\
(2)\end{array}$ & $\begin{array}{l}.9023 \\
(16)\end{array}$ & $\begin{array}{l}167.2 \\
(18)\end{array}$ \\
\hline
\end{tabular}

\subsection{Analysis of molecular packing}

The Hirshfeld surfaces of isatin is shown in Figure 5 while the whole set of intermolecular contacts contributing in its molecular packing are listed in Table 4 and presented graphically in Figure 6 . The molecules are mainly packed by strong $\mathrm{O} \ldots \mathrm{H}$ (41.7\%) and C...C (13.2\%) interactions. These interactions appeared as red regions in the $d_{\text {norm }}$ map indicating significantly short contacts with intermolecular distances shorter than the van der Waals radii sum of the interacting atoms, Figure 7. The shortest interactions are O1...H4 (2.546 $⿱$ ) $)$, O2...H6 (2.466 $⿱ 亠 \mathrm{~A}), \mathrm{O} 1 \ldots \mathrm{H} 1 \quad(1.912 \AA)$ and C7...C8 (3.379 $\AA)$. The short C...C contact distance and the presence of complementary $\mathrm{red} / \mathrm{blue}$ triangles in the shape index map of isatin as indicated by black arrow in Fig. 7 revealed very well the $\pi-\pi$ interactions. The rest of intermolecular contacts are weak and have less significance. For example, the H...H (23.5\%) and H...C $(12.2 \%)$ contacts appeared as white or blue regions in the $d_{\text {norm }}$ indicating weak interactions with intermolecular distances equal or longer than the van der Waals radii sum of the interacting atoms, Figure 7.

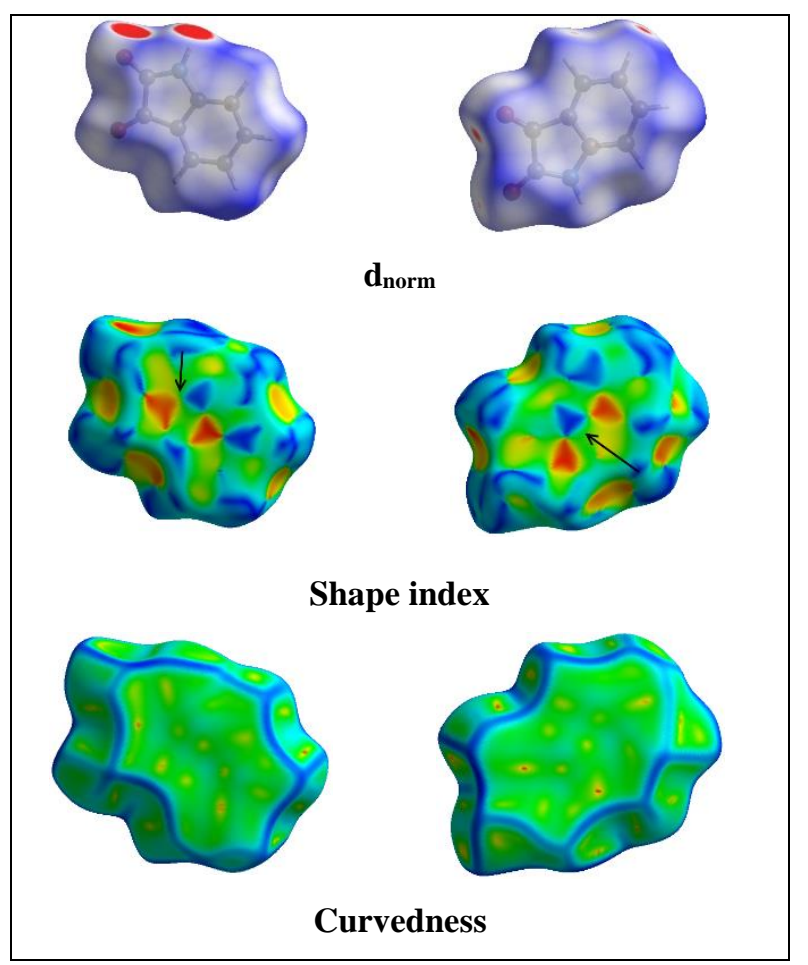

Figure 5. Hirshfeld surfaces of compound 2 
Table 4 Summary of the intermolecular interactions in compound 2

\begin{tabular}{|l|l|}
\hline Contact & Percentage \\
\hline $\mathrm{O} \ldots \mathrm{O}$ & 2.5 \\
$\mathrm{~N} \ldots \mathrm{O}$ & 0.4 \\
$\mathrm{C} \ldots \mathrm{O}$ & 2.2 \\
$\mathrm{O} \ldots \mathrm{H}$ & 41.7 \\
$\mathrm{~N} \ldots \mathrm{H}$ & 1.7 \\
$\mathrm{H} \ldots \mathrm{H}$ & 23.5 \\
$\mathrm{C} \ldots \mathrm{N}$ & 2.6 \\
$\mathrm{H} \ldots \mathrm{C}$ & 12.2 \\
$\mathrm{C} \ldots \mathrm{C}$ & 13.2 \\
$\mathrm{C} \ldots \mathrm{O}$ & 2.2 \\
\hline
\end{tabular}

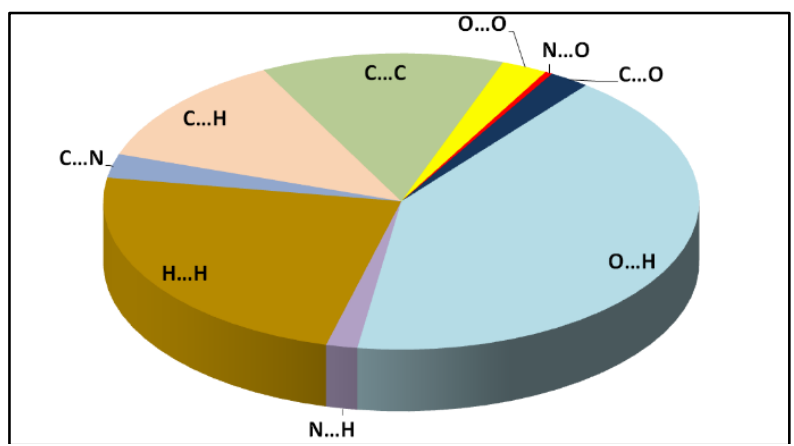

Figure 6. Pie chart showing the weight percentage of the different contacts sharing in the molecular packing of compound 2

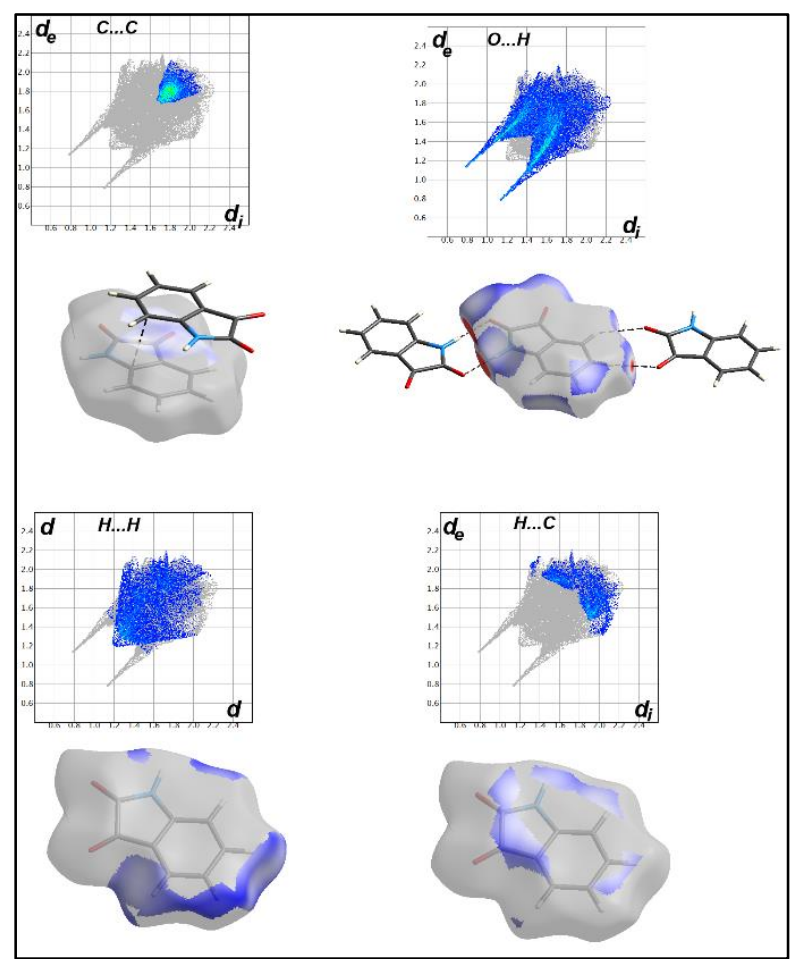

Figure 7. Fingerprint plots (upper) and $d_{\text {norm }}$ surfaces (lower) of the strong O...H and C...C interactions as well as the weak H...H and H...C contacts

\section{DFT studies}

The optimized geometry of compound $\mathbf{2}$ is presented in Fig. 8. Structure matching between the computed molecular geometry with the experimental one indicated very well the agreement between them. The maximum deviation in the bond distances not exceeds $0.04 \AA$ while for bond angles the maximum deviation is $1.8^{\circ}$. The high correlation coefficients between the experimental and calculated geometric parameters are also good indicators on the good agreement between the calculated and experimental structures, Fig. 9.
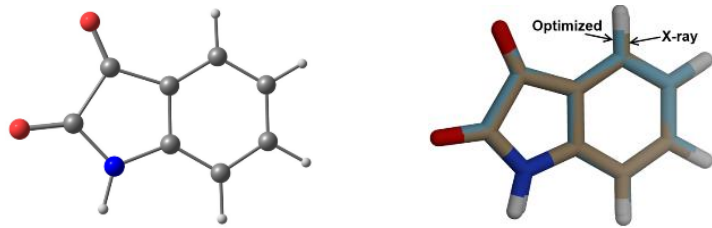

Figure 8. The optimized geometry (left) and overlay of the optimized with experimental structures, (right) for compound 2

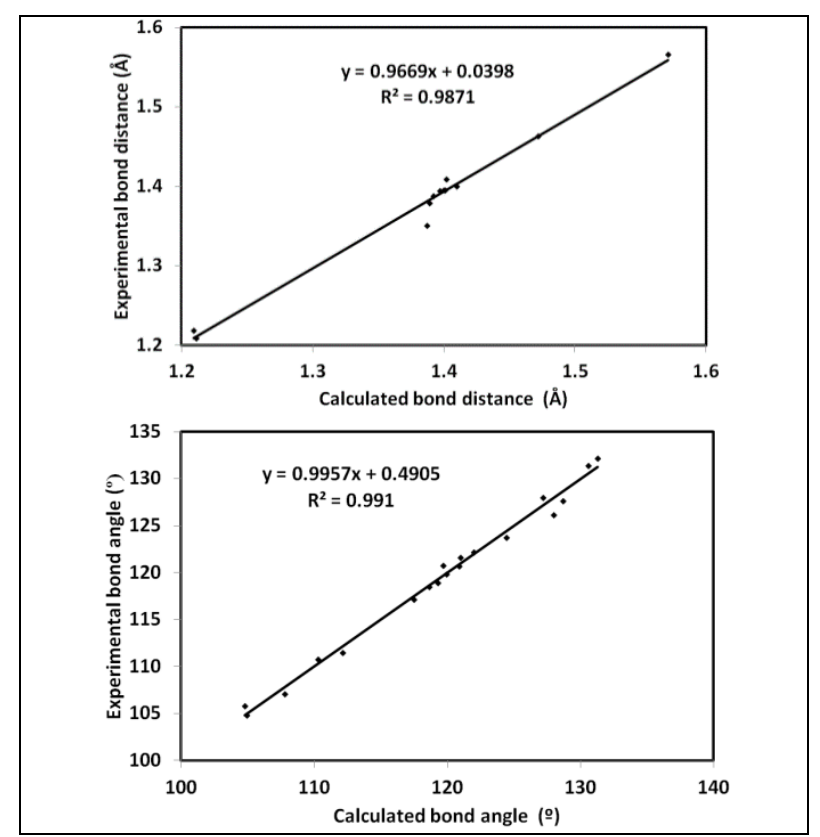

Figure 9. Correlation between the calculated and experimental geometric parameters

The partial atomic charges using NBO method revealed the high electronegative nature of nitrogen and oxygen atoms. The partial charges of the oxygen atoms are -0.478 and -0.533 while the nitrogen has partial charge of -0.647 e. All hydrogen atoms have positive partial positive charges while carbon atoms have negative partial charges except carbon atoms attached directly to electronegative atomic site, Figure 10. For example, the amidic carbon which is directly attached to $\mathrm{N}$ and $\mathrm{O}$ sites has the highest positive 
charge among carbon atoms (+0.622). Also, the molecule is polar with a net dipole moment of 5.9122 Debye.

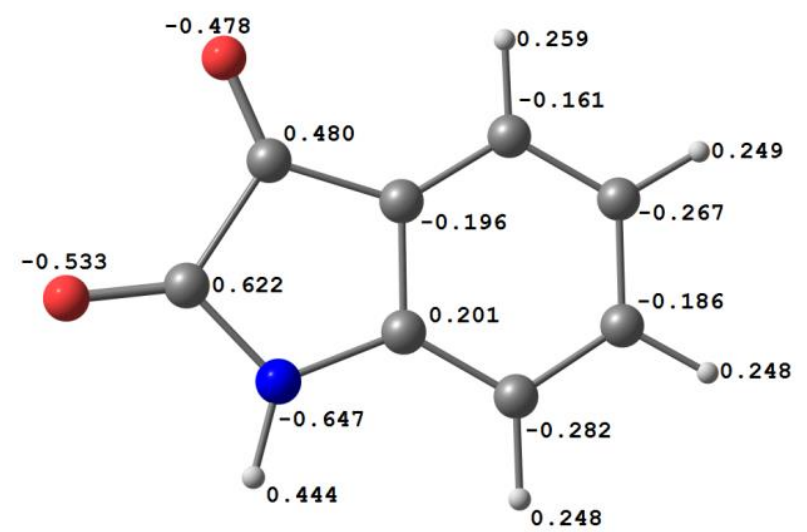

Figure 10. Natural partial atomic charges on the different atomic sites for compound 2

In addition, the molecular electrostatic potential (MEP) mapped over electron density for isatin molecule is shown in Figyre 11. It clearly indicated that the high electron density is related to the carbonyl oxygen atomic sites which are the most preferred sites for hydrogen bonding as hydrogen bond acceptor. In contrast, the blue region around the $\mathrm{N}-\mathrm{H}$ proton suggesting it to be the best site as hydrogen bond donor which agree with the X-ray structure of isatin 2.
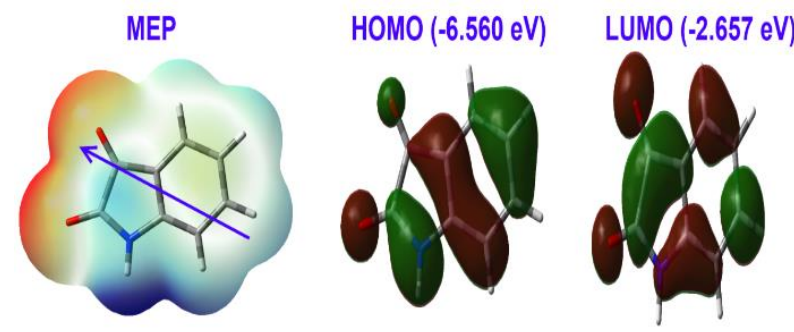

Figure 11. The MEP showing dipole moment vector, HOMO and LUMO of compound 2

The HOMO and LUMO frontier molecular orbitals are also shown in Figure 11. These orbitals and their energies are important for the molecule reactivity (Tannor et al., 1994), (Marten et al., 1996), (Chang et al., 2001), (Sebastian et al., 2010), (Kosar et al., 2011), (Singh et al., 2013). Their energies were calculated to be -6.560 and $2.657 \mathrm{eV}$, respectively. In this regard, the ionization potential (I) and electron affinity (A) are 6.560 and $2.657 \mathrm{eV}$, respectively while the hardness, electrophilicity index and chemical potential are 3.904, 2.720 and $-4.608 \mathrm{eV}$, respectively. As can be seen from the HOMO and LUMO distribution, the lowest energy intramolecular charge transfer has mainly $\pi-\pi^{*}$ transition characters.

\section{Conclusions}

We have been combined a set of phamracophors in one hybrid complex molecule based on indolinone, cyclohexanone, pyrrole and piperidine scaffolds in one pot transformation starting from the chalcone. Isatin architecture is assigned based on $\mathrm{X}$-ray single crystal structure technique. Also, computational studies on isatin were carried out. The biological activity of the target compound will be explored in the near future.

Funding: The authors would like to extend their sincere appreciation to the Researchers Supporting project number (RSP-2020/64), King Saud University, Riyadh, Saudi Arabia.

Conflicts of Interest: The authors declare no conflict of interest.

\section{References}

Arun, Y.; Bhaskar, G.; Balachandran, C.; Ignachimuthu, S.; Perumal, P.T. Facile one-pot synthesis of novel dispirooxindole-pyrrolidine derivatives and their antimicrobial and anticancer activity against A549 human lung adenocarcinoma cancer cell line. Bioorg. Med. Chem. Lett. 2013; 23: 1839-1845.

Barakat A, Islam MS, Ghawas HM, Al-Majid AM, El-Senduny FF, Badria FA, Elshaier YAM, Ghabbour HA. Substituted spirooxindole derivatives as potent anticancer agents through inhibition of phosphodiesterase 1. RSC Adv. 2018; 8: 14335 .

Barakat A, Soliman SM, Alshahrani S, Islam MS, Ali M, Al-Majid AM, Yousuf S. Synthesis, X-ray Single Crystal, Conformational Analysis and Cholinesterase Inhibitory Activity of a New Spiropyrrolidine Scaffold Tethered Benzo[b]thiophene Analogue. Crystals 2020; 10(2): 120.

Chang, R. Chemistry; 7th ed.; McGraw-Hill: New York, NY, USA, 2001.

Frisch, M.J.; Trucks, G.W.; Schlegel, H.B.; Scuseria, G.E.; Robb, M.A.; Cheeseman, J.R.; Scalmani, G.; Barone, V.; Mennucci, B.; Petersson, G.A.; et al. GAUSSIAN 09; Revision A02; Gaussian Inc.: Wallingford, CT, USA, 2009; GaussView; Version 4.1; Dennington II, R., Keith, T., Millam, J., Eds.; Semichem Inc.: Shawnee Mission, KS, USA, 2007. 
Hübschle, C.B.; Sheldrick, G.M.; Dittrich, B. ShelXle: A Qt graphical user interface for SHELXL. J. Appl. Cryst. 2011; 44: 1281-1284.

Kaur M, Singh M, Chadha N, et al. Oxindole: a chemical prism carrying plethora of therapeutic benefits. Eur J Med Chem. 2016; 123: 858-894.

Kosar, B.; Albayrak, C. Spectroscopic investigations and quantum chemical computational study of (E)-4-methoxy-2-[(ptolylimino) methyl] phenol. Spectrochim. Acta 2011, 78, 160-167.

Li G, Lou HX. Strategies to diversify natural products for drug discovery. Med Res Rev. 2018; 38: $1255-1294$.

Lotfy G, Aziz YMA, Said, MM, El Ashry ESH, El Tamany ESH, Barakat A, Ghabbour HA, Yousuf S, Ul-Haq Z, Choudhary MI. Synthesis of oxindole analogues, biological activity, and in silico studies. ChemistrySelect. 2019; 4: 10510.

Lotfy G, El Ashry ESH, Said MM, El Tamany ESH, Aziz YMA, Al-Dhfyan A, Al-Majid AM, Barakat A. Regio-and stereoselective synthesis of new spirooxindoles via 1,3-dipolar cycloaddition reaction: Anticancer and molecular docking studies. J Photochem Photobiol B Biol 2018; 180:98.

Lotfy G, Said MM, El Ashry ESH, El Tamany ESH, Al-Dhfyan A, Aziz, YMA, Barakat A. Synthesis of new spirooxindole-pyrrolothiazole derivatives: Anti-cancer activity and molecular docking. Biorg Med Chem 2017; 25: 1514.

M. J. Turner, J. J. McKinnon, S. K. Wolff, D. J. Grimwood, P. R. Spackman, D. Jayatilaka, M. A. Spackman, Crystal Explorer17 (2017) University of Western Australia. http://hirshfeldsurface.netPUT here the crystal explorer.

Maiuolo, L.; Feriotto, G.; Algieri, V.; Monica, N.; Russo, B.; Di Gioia, M.L.; Furia, E.; Tallarida, M.A.; Mischiati, C.; De Nino, A. Antiproliferative activity of novel isatinyl/indanyl nitrones (INs) as potential spin trapping agents of free radical intermediates. MedChemComm 2018; 9: 299_ 304.

Marten, B.; Kim K.; Cortis, C.; Friesner, R. A.; Murphy, R. B.; Ringnalda, M. N.; Sitkoff, D.; Honig, B. New Model for Calculation of Solvation Free Energies: Correction of Self-Consistent Reaction Field Continuum Dielectric Theory for Short-Range Hydrogen-Bonding Effects, J. Phys. Chem. 1996; 100: 11775-11765.
Newman DJ, Cragg GM. Natural products as sources of new drugs from 1981 to 2014. J Nat Prod. 2016; 79: 629-661.

Reed, A.E.; Curtiss, L.A.; Weinhold, F. Intermolecular interactions from a natural bond orbital, donor-acceptor viewpoint. Chem. Rev. 1988; 88: 899-926.

Rikagu Oxford Diffraction. CrysAlisPro; Agilent Technologies inc.: Yarnton, Oxfordshire, UK, 2018.

S. Sebastian, N. Sundaraganesan, Spectrochim. Acta Part A Mol. Biomol. Spectrosc. 2010; 75: 941-952.

Sheldrick, G.M. SHELXT-Integrated space-group and crystal-structure determination. Acta Cryst. 2015; C71: 3-8.

Singh, R.N.; Kumar, A.; Tiwari, R.K.; Rawat, P.; Gupta, V.P. A combined experimental and quantum chemical (DFT and AIM) study on molecular structure, spectroscopic properties, $\mathrm{NBO}$ and multiple interaction analysis in a novel ethyl 4-[2-(carbamoyl) hydrazinylidene]-3, 5dimethyl-1H-pyrrole-2-carboxylate and its dimer. J. Mol. Strut. 2013; 1035: 427-440.

Tannor, D.J.; Marten, B.; Murphy, R.; Friesner, R.A.; Sitkoff, D.; Nicholls, A.; Ringnalda, M.; Goddard, W.A.; Honig, B. Accurate first principles calculation of molecular charge distributions and solvation energies from ab initio quantum mechanics and continuum dielectric theory. J. Am. Chem. Soc. 1994; 116: 11875-11882.

Tantawy MA, Nafie MS, Elmegeed GA, et al. Auspicious role of the steroidal heterocyclic derivatives as a platform for anti-cancer drugs. Bioorg Chem. 2017; 73:128-146. 